Editorial

\title{
Introduction for the 1st Proctor Lecture
}

The Proctor Lecture was first established under the proposal of ISSMGE-TC 202 "Transportation Geotechnics", coordinated by Professor António Gomes Correia (20012013) and approved at the ISSMGE Board meeting in Paris, September 2013, to commemorate the significant contributions of late Ralph Roscoe Proctor, and to be delivered by the world's most distinguished achievers in Transportation Geotechnics.

Ralph Roscoe Proctor was a famous army engineer in USA during the 1 st world war who invented the Soil Compaction. As a veteran of World War, he was primarily involved in railroad construction work in France. Afterwards, he worked at the California Water Authority of Los Angeles (BWWS - Bureau of Water Works and Supply), where he remained during the rest of his career, mostly involved in construction, design and maintenance. Much of his field experience was diverse in water resources, geo-hydraulics and in situ foundation works. During the construction of Bouquet Canyon Dam (1932-1934), he developed what we now call the "Proctor-test", to determine the optimum water content of the compacted earthfill used for the dam core construction, ensuring both stability and the desired permeability of the compacted fill. He established quantitatively, that for a fixed compression energy imparted to a given soil sample at a known water content, the achievable density would be unique, such that the maximum dry density was attained at the optimum water content. He published these results in 1933 which helped to revolutionise the construction of highways, railroads and airport runways, apart from dams (adapted from Wikipedia and ASCE Transactions, vol. 128, 1963).

The nomination for the inaugural Proctor Lecture took place during the 2013-2017 term of TC202 under chairmanship of Prof. Erol Tutumluer and the choice was the distinguished Professor Buddhima Indraratna (FTSE, FIEAust, FASCE, FGS, FAusIMM, DIC, CEng, CPEng) of University of Wollongong, Australia. The Lecture was decided to be delivered at the 3rd International Conference on Transportation Geotechnics at Guimarães, Portugal, on 5 September 2016.

Professor Buddhima Indraratna was born in the beautiful island of Sri Lanka, where his father was a Professor in
Economics and his mother a medical doctor. For his excellent academic performance in school, he was awarded the Lord Mountbatten scholarship through the Royal family to attend a famous international high school in Wales, the United World College of the Atlantic. After completing the International Baccalaureate examination, he entered the Imperial College of Science and Technology to become a Civil Engineer, a passion he had from his childhood. After graduation in 1982, he worked for a joint partnership between Sir William Halcrow and Partners (UK) and Central Engineering consultancy Bureau (Sri Lanka) in a hydropower dam engineering project in Sri Lanka where he became increasingly interested in geotechnical engineering, even though his real strength was in structural engineering. Buddhima collected data from this project having been part of the design team of the dam spillway and foundation grouting. He returned to Imperial College for a combined Master degree in Soil Mechanics and Engineering Seismology, and worked with Prof Peter Vaughan during his dissertation, inspired by the field experience and data he has acquired. Subsequently he started his $\mathrm{PhD}$ at University of Alberta under Professors Peter Kaiser and Norbert Morgenstern and completed his doctoral thesis in soft rock engineering in 1987.

After getting married during his final year of PhD to Manori whom he met during his studies in London, Buddhima then worked at the Geomechanics Research Centre in Sudbury, initiated by the Ontario government under the leadership of Prof Peter Kaiser. Having worked there for more than a year in underground mining practices, Buddhima decided to accept an academic position at the Asian Institute of Technology in Bangkok, Thailand, where as an Assistant Professor and then promoted to Associate Professor, he learnt the art of soft clay engineering swiftly and expanded his teaching and research interests from rock engineering to soft clay improvement and transport geotechnics. After 3 years in Thailand, Buddhima decided to migrate to Australia with his wife and 3 year old son in August 1991, and joined University of Wollongong as a Lecturer in Geotechnical Engineering, where he excelled in research, and pioneered the areas of Ground 
Improvement and Transport Geotechnics in Australia. He was particularly passionate in railway geotechnics, an area which in his view was totally neglected in Australia. Buddhima developed the University of Wollongong's geotechnical laboratories and other research facilities from a modest level to state-of-the-art in quick time, and was promoted to professor within 8 years. Today, he is a Distinguished Professor, arguably the highest echelon of the Australian professoriate.

His teaching and research over 25 years at the University of Wollongong has been inspirational, and a rare winner of the highest awards at the University for both teaching and research. He has worked with industry in several countries, and has been a United Nations Expert and a Foreign Advisor to numerous overseas projects. His significant contributions to geotechnical and railway engineering have been acknowledged through numerous national and international awards. Apart from this inaugural Ralph Proctor Lecture, he will also deliver the 4th Louis Menard Lecture for Ground Improvement in Seoul at the forthcoming International Conference of Soil Mechanics and Geotechnical Engineering. He was also the recipient of 2015 Thomas Telford Premium Award for Ground Improvement. In 2014, he received the CS Desai Excellence Medal by the International Association of Computer Methods and Advances in Geomechanics (IACMAG). In 2010, he delivered the prestigious E. H. Davis Memorial Lecture of Australian Geomechanics Society for distinguished contributions to theory and practice of geomechanics. For his pioneering contributions to railway innovations, he was honored with the Business and Higher Education award by the Australian Government in 2009 and the prestigious Engineers Australia Transport Medal in 2011. Recently, the State Minister of Transport awarded Buddhima, the 2015 Australasian Railway Society's Outstanding Individual Award at the Parliament House of New South Wales.

Buddhima currently leads numerous projects funded by the Australian Research Council with over \$20 million dollars over the past decade. He has more than 650 publications including 9 Books and over 270 scholarly journal papers. He has supervised over $50 \mathrm{PhD}$ graduates and 30 Postdoctoral Fellows. He is a Fellow of several professional bodies including the most prestigious Australian Academy of Technological Sciences and Engineering, as well as a Fellow of several professional organizations including the Institution of Engineers, Australia, the American Society of Civil Engineers, and the Geological Society of UK.

His contributions have led to advances in analytical and numerical methods which improve delivery of services and economic returns through improved efficiency, in the design and operation of basic infrastructure, particularly the roads and rail transportation embankments. Some noteworthy efforts include: Port of Brisbane and Port Kembla-Wollongong reclamation works, Ballina Bypass in New South Wales, and Sunshine Coast road embankment in Queensland, rail track design and analysis in the town of Sandgate, Singleton and Bulli in the state of New South Wales, NSW, and more recently a key consultant to several Australian companies in soil testing design aspects of Inland Rail to be constructed over $2000 \mathrm{~km}$ connecting the major cities of Brisbane, Sydney and Melbourne. Overseas projects include performance analysis of Second Bangkok International Airport, Geosynthetic applications for Indian Railways; Tsunami rehabilitation of roads and railways in Sri Lanka, Advising Thai government officials on major track modernization, among several other projects over the past two decades. Through his long standing R \& D efforts, he was directly responsible for initiating Australian Standards for execution of prefabricated vertical drains for road embankments, in 2011), and the revision of rail ballast standards for the state of New South Wales in 2009.

His active involvement in various national and international advisory committees, as well as serving the editorial Boards of 7 well-known international journals over a long period of time is commendable. For instance, he is an Associate Editor for ASCE Journal or Geotechnical and Geoenvironmental Engineering and the Canadian Geotechnical Journal. He has been a core member of 4 ISSMGE Committees including Transport Geotechnics and Ground Improvement. He was one of the 3 pioneers who formed the ISSMGE Working Group on Natural Disaster Prevention and Rehabilitation in early 2005, after the catastrophic Asian Tsunami.

I got to know Buddhima at the International Conferences of ISSMGE appreciating always the enthusiasm he puts in his activities. In fact, it was after he joins TC202 that we became good friends enjoying the faces of professional and personal life.

I'm sure we are all anticipating a lecture of practical importance and scientific significance.

António Gomes Correia
University of Minho, Portugal
Accepted 19 May 2016

Available online 24 May 2016 